\title{
CORRESPONDENCE.
}

\section{ON THE LOADING OF ASSURANCE PREMIUMS.}

To the Editor of the Journal of the Institute of Actuaries.

SiR,-Considering that every actuary has occasion to deal frequently with this question, and looking to its important bearing on the interests of his company, I am rather surprised that it has not obtained a more prominent place in our discussions.

In the great majority of published tables, the computer seems to have been content to increase the net or pure premiums by an arbitrarily fixed ratio, while, supported by the high authority of $\mathrm{Mr}$. Jellicoe (see Assurance MLagazine, volume x, page 336), a modified method appears to be now frequently acted on, which consists in making two additions, one of them a percentage of the net premium in respect of the outlay for agents' commission and of profit to be made by the transaction, and the other a percentage on the sum assured, which is the same at all ages, to cover the "going" office expenses incurred in the collection and investment of the premiums, and in its continued general management. This is obviously but an imperfect substitute for the older method, seeing it but changes the measure of the charge, from the premium to the sum assured; and (assuming that the fixed charge should be the same on each policy) it could only be corrected by tabulating a graduated scale of premiums for the assurance for $£ 100, £ 200$, $\$ 300$, \&c., at each age. Apart from the last objection, however, I have been led on examination to doubt whether, on any reasonable hypothesis of the ratio of expense usually incurred, the theory of a fixed addition is tenable.

In late discussions on the rate of expenditure of well-conducted offices, it has been found that an outlay of 50 per-cent of the first year's 
premium revenue, and 7 per-cent of the renewals, is a fair indication of the disbursement for management. To find therefore a premium which, when lessened by this charge, and computed to meet a benefit increased by a proportion for office profit, let $\mathrm{P}$ be such a premium. Its value, when the foregoing deductions are made, will be

$$
\mathrm{P}(1+a)-\mathrm{P}(\cdot 5+\cdot 07 a)=\mathrm{P}(\cdot 93 a+\cdot 5) ;
$$

and if $q$ per unit be the loading for profit, we shall have

$$
\mathrm{P}(\cdot 93 a+\cdot 5)=\mathrm{A}(1+q) \text {, }
$$

whence

$$
\mathrm{P}=\frac{\mathrm{A}(1+q)}{.93 a+\cdot 5}
$$

Taking $q=\cdot 1$, by the four per-cent $\mathrm{H}^{\mathrm{M}}$ table we obtain the following results:- - the premiums being those chargeable at the ages indicated,

\begin{tabular}{|c|c|c|c|}
\hline $\begin{array}{l}\text { Age. } \\
20\end{array}$ & $\begin{array}{c}\text { Premium per-cent. } \\
1.5075\end{array}$ & \multirow{2}{*}{\multicolumn{2}{|c|}{$\begin{array}{l}\text { Loading. } \\
21 \cdot 1 \text { per-cent }\end{array}$}} \\
\hline 30 & $2 \cdot 0261$ & $21 \cdot 4$ & \\
\hline 40 & $2 \cdot 8636$ & 21.8 & ", \\
\hline 50 & 4.3371 & 22.5 & " \\
\hline 60 & $7 \cdot 0723$ & $23 \cdot 8$ & , \\
\hline
\end{tabular}
and the third column showing the proportion of "loading" requisite to be added to the net premium to produce the same result:-

It will be seen that the ratio of loading increases with the age, while a premium computed on the method of making a fixed extra at all ages would exhibit from its nature a diminishing ratio.

The latter method may be expressed by the equation

$$
\varpi x+y=\mathrm{P},
$$

where, $\mathrm{P}$ being ascertained, it is required to determine the numbers $x$ and $y$ which would (founded on the net premium) produce it. This is amenable to the treatment so ingeniously made available by Mr. Sprague in his late paper* on office expenses; and, following his application of the doctrine of least squares for arriving at a correct average of the five rates above quoted, we find

$$
x=1.306 \text { and } y=-2318 \text {, }
$$

leaving the fixed amount to be subtracted from the product of $x$ and the net premium. The application of these numbers to the net premium gives the following results:-

$\begin{array}{lcc}\text { Age. } & \text { Premium per-cent. } & \text { Loading per-cent. } \\ 20 & 1 \cdot 3935 & 12 \cdot 0 \\ 30 & 1 \cdot 9483 & 16 \cdot 7 \\ 40 & 2 \cdot 8395 & 20 \cdot 7 \\ 50 & 4 \cdot 3934 & 24 \cdot 1 \\ 60 & 7 \cdot 2322 & 26 \cdot 6\end{array}$

The weight of evidence consequently goes to prove that this method of loading can hardly be an improvement on the older one,

* The reference here is to a letter in the Insurance Record for 10 March 1876, the substance of which we hope to place before our readers at some future date. -ED. J.I. $A$. 
and I hope the present contribution to the general question will elicit something that may be found more useful.

An opinion, for which I think we were first indebted to a German writer*, was ventilated lately at a discussion in the Institute, to the effect that at any valuation of a current policy made professedly on a "net premium" system, it would be right to deal with the value of the premium as an increasing one, although the actual rate paid by the assured does not alter. Thus in the case herein explained, it may be assumed that the net premium paid for the first year's assurance should do no more than cover the risk for the term, the excess of the actual payment ranking as "loading." To compensate for this, the after premiums should be estimated as greater than the ordinary net premiums for the whole of life, such increased premiums being taken credit for at a valuation.

The argument is not without interest, and it may be well to exhibit the following figures in illustration of it.

The total premiums assumed are those resulting from the formula

$$
\mathrm{P}_{x}=\frac{100 \mathrm{~A}_{x}}{.93 a_{x}+\cdot 5}
$$

by the $\mathrm{H}^{\mathrm{M}}$ table at three per-cent without farther addition.

\begin{tabular}{|c|c|c|c|c|}
\hline $\begin{array}{l}\text { Age. } \\
\text { (1) }\end{array}$ & $\begin{array}{c}\text { First Year's } \\
\text { Net Premium. } \\
\text { (2) }\end{array}$ & $\begin{array}{c}\text { Future Annual } \\
\text { Net Premium. } \\
\text { (3) }\end{array}$ & $\begin{array}{l}\text { Whole of Life } \\
\text { Net Promium. } \\
\text { (4) }\end{array}$ & $\begin{array}{c}\text { Percentage of } \\
\text { Inerease oredited. } \\
\text { (5) }\end{array}$ \\
\hline $\begin{array}{l}20 \\
30 \\
40 \\
50 \\
60\end{array}$ & $\begin{array}{r}7835 \\
1 \cdot 0334 \\
1 \cdot 4283 \\
2 \cdot 1087 \\
3 \cdot 3572\end{array}$ & $\begin{array}{l}1.4572 \\
1.9221 \\
2 \cdot 6567 \\
3.9222 \\
6.2444\end{array}$ & $\begin{array}{l}1 \cdot 4272 \\
1 \cdot 8795 \\
2 \cdot 5891 \\
3 \cdot 8005 \\
5 \cdot 9874\end{array}$ & $\begin{array}{l}2 \cdot 10 \\
2 \cdot 27 \\
2 \cdot 61 \\
3 \cdot 20 \\
4 \cdot 29\end{array}$ \\
\hline
\end{tabular}

Opposite the age at entry are given-

In Column (2). The net premium received for the first year's assurance (by hypothesis one half of the entire payment made by the assured).

" " (3). The net premium paid thereafter, being the whole payment less 7 per-cent spent in management.

" , (4). The ordinary or net tabulated premium for the whole of life assurance.

Column (3) exhibits the net premium for which credit would be taken under such a system of valuation, in contradistinction to the amount in Column (4). The last column exhibits the ratio of increase thus valued, which it will be seen is considerable.

Had the premium payable by the assured been of the usual form of an ordinary net premium for the whole of lite, its alteration by the above system would have exhibited a greater discrepancy when the equivalent for the half of the first year's payment was added to it.

Something may be said for the adoption of the practice so long

* See Journal xv, 420. 
as the smaller premium reserved for the first year's assurance is in any measure in excess of the value of the risk run by the company during that year, but it is, to say the least, disingenuous to adopt the popular definition and to describe such a valuation as a "net premium" one.

I am, Sir,

Your most obedient servant,

London.

H. AMBROSE SMITH.

** As the latter part of the above letter deals to some extent with the same subject as Mr. McCandlish's paper, published in the last number of the Journal, Mr. Smith wishes us to mention that it was in type before he had heard of Mr. MeCandlish's essay.--ED. J.I. A.

\section{MR. DEUCHAR'S PAPER ON NEGATIVE POLICY-VALUES.}

\section{To the Editor of the Journal of the Institute of Actuaries.}

SrR,-The question discussed by Mr. W. T. Gray, in his interesting letter in the Oct. Number of the Journal (p. 73), is one of importance. $\mathrm{He}$ has shown by figures that, at any rate in one particular case, it is a matter of indifference to a company which so treats its policies as to convert many of them into assets instead of liabilities, whether it value at long or short intervals of time. But an arithmetical demonstration, however useful in illustration of one more general, is not altogether satisfactory by itself; and on this account, as well as because Mr. Gray appears to have fallen in one respect into a little confusion, I venture to trouble you with a brief mathematical proof.

Let us suppose two companies, A and B, identical, to start with, in every respect, doing an identical amount and description of business, and making the same rate of interest, say $i$, on their funds; and let them value on the same basis, and so that all policies have negative values for $t$ years. Let, however, A divide its profits annually, and B septennially. At the beginning of any given septennium, the two companies will be identical in position. At the end of the first year of that septennium $A$ will distribute a certain surplus, say $m_{1}$; at the end of the second year another, $m_{2}$; and so on; and at the end of the seventh year, $m_{7}$. At the end of the first year let $B$ also make a valuation for the private information of its manager, but let it retain in hand the discovered surplus, which will also be $m_{1}$, and carry it to a separate account in its ledger. Except for a book entry, it is precisely as it would have been had it not made an investigation, and its life funds proper are of the same amount as those of $\mathbf{A}$ at the same instant of time, only they are supplemented by the sum $m_{1}$ in the suspense account. At the end of the second year let the same process be repeated. In addition to the first surplus, now grown to $m_{1}(1+i)$, it brings out another, which must be $m_{2}$, and treats it in a similar manner, and so on to the end of the septennium, when the total surplus-now to be distributed-in its funds will be-

$$
m_{1}(1+i)^{6}+m_{2}(1+i)^{5}+\ldots .+m_{6}(1+i)+m_{7},
$$

or exactly equal to the profits declared by $A$, accumulated at interest. 